\title{
Preparation and Characterization of Magnesium Stearate, Cobalt Stearate, and Copper Stearate and Their Effects on Poly(vinyl chloride) Dehydrochlorination
}

\author{
M. Gönen, ${ }^{1}$ T.O. Egbuchunam, ${ }^{2}$ D. Balköse, ${ }^{3}$ F. İnal, ${ }^{3}$ S. Ülkü ${ }^{3}$ \\ ${ }^{1}$ Süleyman Demirel University, Department of Chemical Engineering, 32260 Isparta, Turkey \\ ${ }^{2}$ Federal University of Petroleum Resources of Efferune, Department of Chemistry, Delta State, Nigeria \\ ${ }^{3}$ Department of Chemical Engineering, Izmir Institute of Technology, Gülbahçe, Urla, 35430 izmir, Turkey
}

\begin{abstract}
Preparation and characterization of pure metal soaps and investigation of their effects on poly(vinyl chloride) (PVC) dehydrochlorination were the objectives of the present study. Magnesium stearate $\left(\mathrm{MgSt}_{2}\right)$, cobalt stearate $\left(\mathrm{CoSt}_{2}\right)$, and copper stearate $\left(\mathrm{CuSt}_{2}\right)$ were prepared by a precipitation method. An aqueous sodium stearate (NaSt) solution was mixed at 500 rpm with respective metal salt solutions at $75^{\circ} \mathrm{C}$. The precipitates that formed were collected by filtration, washed with water, and ultimately dried at $105^{\circ} \mathrm{C}$ under reduced pressure. Lamellar crystals that melted on heating were obtained. Solid-liquid phase transitions were observed by optical microscopy at $160^{\circ} \mathrm{C}, 159^{\circ} \mathrm{C}$, and $117^{\circ} \mathrm{C}$ for $\mathrm{MgSt}_{2}, \mathrm{CoSt}_{2}$, and $\mathrm{CuSt}_{2}$, respectively. However, the melting points of $\mathrm{MgSt}_{2}, \mathrm{CoSt}_{2}$, and $\mathrm{CuSt}_{2}$ were determined as $115^{\circ} \mathrm{C}, 159^{\circ} \mathrm{C}$, and $111^{\circ} \mathrm{C}$, respectively, by analysis by differential scanning calorimetry. The onset temperature of the mass loss was the lowest at $255^{\circ} \mathrm{C}$ for $\mathrm{CuSt}_{2}$ and the lowest activation energy for thermal decomposition was $18 \mathrm{~kJ} / \mathrm{mol}$ for $\mathrm{CuSt}_{2}$. $\mathrm{CoSt}_{2}$ was effective in extending the induction time of PVC dehydrochlorination at both $140^{\circ} \mathrm{C}$ and $160^{\circ} \mathrm{C}$. The activation energy calculated from stability time decreased from $175 \mathrm{~kJ} / \mathrm{mol}$ for a blank PVC sample to 114, 105, and $107 \mathrm{~kJ} / \mathrm{mol}$ for $\mathrm{MgSt}_{2}, \mathrm{CoSt}_{2}$, and $\mathrm{CuSt}_{2}$-containing PVC samples, respectively. All three metal soaps accelerated the dehydrochlorination of PVC. J. VINYL ADDIT. TECHNOL., 21:235-244, 2015. (c) 2014 Society of Plastics Engineers
\end{abstract}

\section{INTRODUCTION}

Metal soaps are compounds of long-chain fatty acids with metals having different valences. Depending on the nature of the cation, alkyl chain length, and presence or absence of double bonds in the chain, the physical properties of metal carboxylates may vary considerably. They are generally water-insoluble, but may be soluble in some

Correspondence to: D. Balköse; e-mail: devrimbalkose@iyte.edu.tr DOI 10.1002/vnl.21384

Published online in Wiley Online Library (wileyonlinelibrary.com).

(C) 2014 Society of Plastics Engineers organic solvents in which they commonly exhibit Kraffttype behavior, with solubilities increasing dramatically above a particular temperature [1].

Metal soaps are produced in different forms, such as fine powders, flakes, and granules. They are usually produced by using precipitation or fusion techniques. Although the precipitation method produces very light, fine powders with a high surface area, the fusion technique produces flakes or pellets. Another issue relating to the product purity is that for the precipitation process, products with a high purity can be obtained by washing and filtering $[2,3]$. For products used in the pharmaceutical and food industries especially, purity is a major concern. Magnesium stearate is widely used in drug formulations. The production of $\mathrm{MgSt}_{2}$ throughout the world is based either on the reaction of stearic acid with a magnesium compound such as carbonate, oxide or on the reaction of magnesium chloride with sodium or ammonium stearate in aqueous solution, leading to the precipitation of the dihydrate. $\mathrm{CoSt}_{2}$ was synthesized by double decomposition of cobalt acetate with sodium stearate (NaSt) according to a previously reported procedure. The thermal characterization and other physicochemical properties of cobalt stearate have been reported $[4,5]$. $\mathrm{CuSt}_{2}$ is prepared by the interaction of an aqueous NaSt solution with copper sulfate solution. There are other methods for metal soap synthesis. For example, a super-hydrophobic copper surface with a $153^{\circ}$ contact angle was obtained by coating copper electrodes with $\mathrm{CuSt}_{2}$. This was accomplished by applying a DC voltage to copper electrodes immersed in stearic acid solution [6].

Magnesium stearate, cobalt stearate, and copper stearate have many industrial applications. Magnesium stearate is in widespread use as gelling, sanding, and antisticking agents, stabilizers, lubricants, emulsifiers, and plasticizers for polymers, in paint, food, rubber, paper, and pharmaceutical industries [7]. Magnesium soaps are also used as batting agents to reduce the gloss of paints 
and varnishes and also to thicken paints. $\mathrm{MgSt}_{2}$, with its low coefficient of friction and large "covering potential," is an ideal lubricant and is widely used in tablet manufacturing [8]. Aerosol performance of micronized drug powders can be increased by coating with magnesium stearate. The agglomerate strength of the powders is decreased by the coating process [9]. Stable semisolid lipogels with $\alpha$-crystalline lamellar phases can be prepared from magnesium stearate and water in liquid paraffin [10]. Cobalt stearate is used as a prooxidant additive in polyethylene to accelerate the rate of degradation in the environment [4]. Cobalt stearate has applications in producing Co nests [11], mesoporous silica [12], and as an adhesion promoter in the curing of rubber [7]. $\mathrm{CuSt}_{2}$ can be used in the detection of volatile organic compounds. The vibration frequency of the crystal changes as organic compounds are adsorbed on $\mathrm{CuSt}_{2}$ [13].

Metal soaps are the most used heat stabilizers for poly(vinyl chloride) (PVC). The carboxylate group of the metal salt replaces the tertiary or allylic chlorine atoms and inhibits the initiation of dehydrochlorination. Magnesium stearate has been used for the thermal stabilization of PVC [14]. Copper-containing layered double hydroxides affect the thermal and smoke behavior of PVC [15]. Metal dicarboxylates are effective in retarding the dehydrochlorination reaction of PVC [16].

Magnesium stearate, cobalt stearate, and copper stearate have a wide range of applications in industry. In this case, these salts were generated by the addition of metal salt solutions to aqueous NaSt solutions. The effects of these soaps on the thermal dehydrochlorination of PVC powder have been investigated.

\section{EXPERIMENTAL}

\section{Materials}

NaSt, $\mathrm{C}_{17} \mathrm{H}_{35} \mathrm{COONa}$ (commercial product, Dalan Kimya A.S., Turkey), was used in the synthesis of metal soaps. The acid value of the commercial stearic acid, used in $\mathrm{NaSt}$ synthesis, was $208.2 \mathrm{mg} \mathrm{KOH} / \mathrm{g}$. It consists of $47.7 \%$ palmitic acid and $52.3 \%$ stearic acid. Magnesium sulfate heptahydrate, cobaltous chloride hexahydrate, and copper sulfate pentahydrate (Merck) were used in precipitating metal soaps.

\section{Precipitation Process}

A sample of $5.000 \mathrm{~g}(0.016 \mathrm{~mol})$ of NaSt was dissolved in $200 \mathrm{~cm}^{3}$ of deionized water in the reactor at $75^{\circ} \mathrm{C}$. Because NaSt is partly soluble at low temperatures, temperature of dissolution was selected as $75^{\circ} \mathrm{C}$. The metal salt $(0.012 \mathrm{~mol})(50 \%$ excess of theoretical amount) was dissolved in $100 \mathrm{~cm}^{3}$ of deionized water at $30^{\circ} \mathrm{C}$ and added to the sodium soap solution immediately at $75^{\circ} \mathrm{C}$. The reaction temperature was maintained at $75^{\circ} \mathrm{C}$ by a PID temperature controller (Love Controls Series 2500). The mixture was stirred at a rate of $500 \mathrm{rpm}$ for $30 \mathrm{~min}$ by a mechanical stirrer. Because the byproduct salts are soluble in water, the reaction media were filtered by using a Büchner funnel and flask at $2 \times 10^{4} \mathrm{~Pa}$ pressure. To remove the byproduct $\mathrm{NaCl}$ or $\mathrm{Na}_{2} \mathrm{SO}_{4}$ completely, wet metal soaps were washed with $200 \mathrm{~cm}^{3}$ deionized water and the wet metal soap cake was dried at $105^{\circ} \mathrm{C}$ and $2 \times 10^{4} \mathrm{~Pa}$ pressure.

\section{Characterization of Metal Soap Powders}

The crystalline structure and purity of the metal soap samples were determined by means of X-ray powder diffraction (Philips Xpert-Pro) with $\mathrm{CuK}_{\alpha}$ radiation at $45 \mathrm{kV}$ and $40 \mathrm{~mA}$. The X-ray scans were performed in the 5$60^{\circ} 2 \theta$ range. Scanning electron microscopy (SEM) (Philips XL30 SFEG), with energy dispersive X-ray (EDX) analyses, was used for the identification of particle size and product purity. The samples were coated with gold and palladium metals by using the sputtering technique. Fourier-transform infrared (FTIR) spectroscopy (Shimadzu 8601) was used to obtain the FTIR spectra of the products. For the preparation of metal soap samples for infrared analysis, the $\mathrm{KBr}$ disc method was used. Metal soap (4 mg) and $196 \mathrm{mg}$ of $\mathrm{KBr}$ were mixed and pressed into $1-\mathrm{cm}$ discs under 10 tons of load. EDX analysis was used to determine the product constituents and check the removal of byproducts, $\mathrm{NaCl}$ or $\mathrm{Na}_{2} \mathrm{SO}_{4}$. The melting behavior of the metal soaps was monitored by using an optical microscope (Olympus $\mathrm{CH} 40$ ) equipped with a hot stage (Olympus CH40 INSTEC, hot stage). The color of the samples was measured by using a fiber optic spectrophotometer (Aventes-2048 Spectrophotometer).

\section{PVC Dehydrochlorination Tests}

Emulsion-type PVC (Petvinil 38/74, PETKIM, Turkey) [17] was used to test the effect of metal soaps on the thermal dehydrochlorination of PVC. Metal soap (3\% in mass, 0.005 mole/100 g) was mixed with PVC powder in a ceramic mortar. The powder mixture was collected at the center by a stainless steel spatula and distributed evenly to the inner surface of the mortar by the movement of the ceramic pestle in small circles. The collection and distribution operation was carried out at least 10 times to obtain even dispersion of the metal soap particles in PVC powder. Thermal degradation studies were carried out by using pure PVC and on these mixtures at $140^{\circ} \mathrm{C}$ and $160^{\circ} \mathrm{C}$ by using a 763 PVC Thermomat (Metrohm). The samples $(0.5 \mathrm{~g})$ were heated in glass tubes under constant flow of nitrogen gas. Released $\mathrm{HCl}$ formed by the thermal decomposition was carried by the stream of nitrogen flowing at a rate of $6.7 \mathrm{dm}^{3} / \mathrm{h}$ into the measuring cell filled with $60 \mathrm{~cm}^{3}$ distilled water. The $\mathrm{HCl}$ dissolved in water increases the electrical conductivity. The conductivity change for each measuring cell with time was recorded by a computer. The thermal stability of the PVC materials was measured in terms of the onset time for degradation and stability time for the polymer. Onset time 


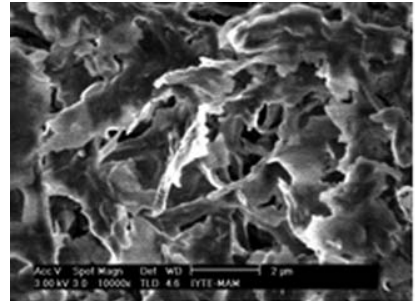

(a)

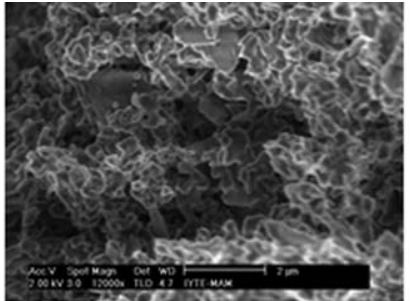

(b)

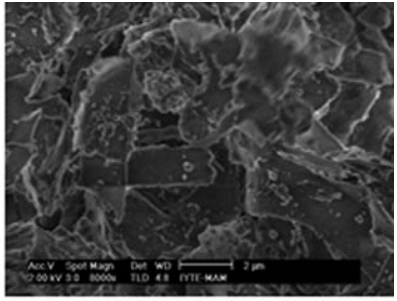

(c)

FIG. 1. SEM micrographs of (a) magnesium soap, (b) copper soap, (c) cobalt soap at $\times 5,000$ magnification.

is the time that elapses until the conductivity of test water starts to increase and the stability time is the time passed until the conductivity reached $50 \mathrm{mS}$. After the thermal degradation test, the color of samples was measured by using the fiber optic spectrophotometer (Aventes-2048 Spectrophotometer).

\section{RESULTS AND DISCUSSION}

\section{Morphology and Order in Metal Soaps}

The morphologies of the metal soaps are seen in Fig. 1. All three soaps, $\mathrm{MgSt}_{2}, \mathrm{CuSt}_{2}$, and $\mathrm{CoSt}_{2}$, consisted of lamellar particles for $\mathrm{MgSt}_{2}, \mathrm{CuSt}_{2}$, and $\mathrm{CoSt}_{2}$, respectively. The thickness of the particles was very small (around $50 \mathrm{~nm}$ ) compared with their length and width. The flat surfaces of the powders are $0.5 \times 2 \mu \mathrm{m}, 0.3-0.5 \mu \mathrm{m}$, and $1 \times 2 \mu \mathrm{m}$ size for $\mathrm{MgSt}_{2}, \mathrm{CuSt}_{2}$, and $\mathrm{CoSt}_{2}$, respec-

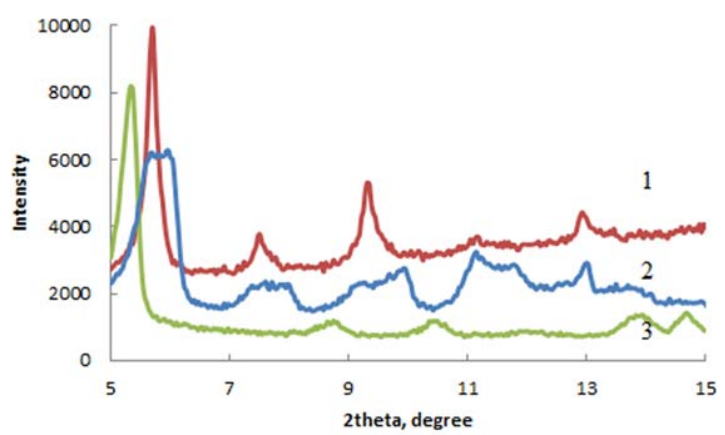

(a)

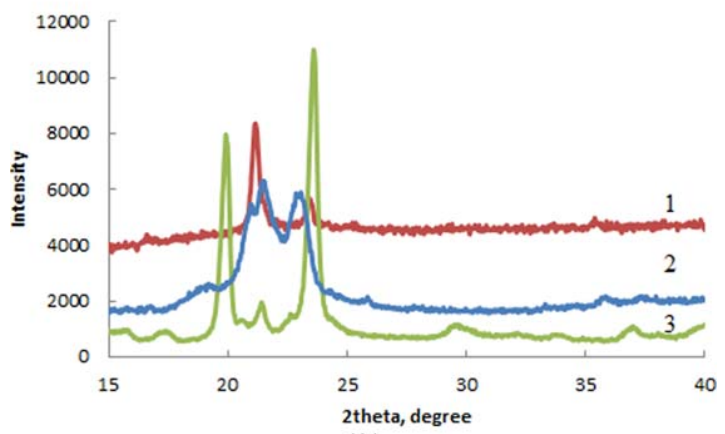

(b)

FIG. 2. X-ray diffraction diagrams of the metal soaps at $2 \theta$ (a) $5-20^{\circ}$, (b) $15-40^{\circ}$, (1) cobalt soap, (2) copper soap, (3) magnesium soap. [Color figure can be viewed in the online issue, which is available at wileyonlinelibrary.com.] tively. The small particle size of the powders allows them to mix uniformly with polymer powders when they were used as additives.

The bilayer distance of metal soaps can be determined by X-ray diffraction. For example, X-ray diffraction peaks at $2 \theta$ values of 3,5 , and $9^{\circ}$ could be observed for magnesium stearate [18]. The X-ray diffraction diagrams of the powders (Fig. 2a) were analyzed for bilayer distance (Table 1). From the third-, fourth-, fifth-, and seventhorder diffraction peaks, the bilayer distance was determined to be 5.0, 4.7, and $4.5 \mathrm{~nm}$ for $\mathrm{MgSt}_{2}, \mathrm{CuSt}_{2}$, and $\mathrm{CoSt}_{2}$, respectively, by using Braggs law:

$$
n \lambda=2 d \operatorname{Sin} \theta
$$

where $\lambda$ is the wavelength of the X-rays, $0.1546 \mathrm{~nm}$ for $\mathrm{CuK}_{\alpha}$ radiation; $n$ is the order of diffraction; $d$ is the bilayer distance; and $\theta$ is the diffraction peak angle. The alkyl groups were oriented perpendicular to the metal layer in $\mathrm{MgSt}_{2}$ because the bilayer distance (i.e., $5 \mathrm{~nm}$ ) was equal to the length of two stearate groups. Alkyl groups were perpendicular to the planes of the metal layer. On the other hand, the alkyl groups made $70^{\circ}$ and $64^{\circ}$ angles with the surface of the metal layer for $\mathrm{CoSt}_{2}$ and $\mathrm{CuSt}_{2}$.

The alkyl groups of the metal soaps can be arranged in orthorhombic $(a=0.74, \quad b=4.93$, and $c=2.53)$ and monoclinic $(a=8.09, b=2.53, c=4.79)$ structures [19]. As seen from the diffraction peaks observed in Fig. 2b and reported in Table 2, although magnesium soap had mainly orthorhombic unit cells, the copper and cobalt soaps crystallized in monoclinic unit cells. Crystal size in the perpendicular direction to 200 planes of the orthorhombic unit cells are $35.4,27.1$, and $54.2 \mathrm{~nm}$ as

TABLE 1. $2 \theta$ values of X-ray diffraction peaks of different orders of the bilayer distances of metal soaps and their bilayer distances.

\begin{tabular}{lccc}
\hline $\begin{array}{l}\text { Order of } \\
\text { diffraction }\end{array}$ & $\begin{array}{c}\text { Magnesium } \\
\text { soap }\end{array}$ & $\begin{array}{c}\text { Cobalt } \\
\text { soap }\end{array}$ & $\begin{array}{c}\text { Copper } \\
\text { soap }\end{array}$ \\
\hline 3 & 5.34 & 5.78 & 5.95 \\
4 & - & 7.51 & 8.02 \\
5 & 8.82 & 9.35 & 9.88 \\
6 & 10.52 & 11.19 & 11.59 \\
7 & 13.90 & 12.99 & 13.03 \\
Bilayer & 5.0 & 4.7 & 4.5 \\
$\quad$ distance, nm & & & \\
\hline
\end{tabular}


TABLE 2. Organization of the alkyl group of the soaps, observed peak maxima, $2 \theta$ degree and Miller Indices (h $\mathrm{k} 1$ values) of crystal planes.

\begin{tabular}{llccc}
\hline $\begin{array}{l}\text { Crystal } \\
\text { plane hkl }\end{array}$ & $\begin{array}{c}\text { Unit cell } \\
\text { geometry }\end{array}$ & $\begin{array}{c}\text { Magnesium } \\
\text { soap }\end{array}$ & $\begin{array}{c}\text { Copper } \\
\text { soap }\end{array}$ & $\begin{array}{c}\text { Cobalt } \\
\text { soap }\end{array}$ \\
\hline 222 & Orthorhombic & 19.9 & - & - \\
220 & Orthorhombic & - & 20.9 & - \\
200 & Monoclinic & 21.32 & 21.32 & 21.12 \\
200 & Orthorhombic & 23.59 & 22.8 & 23.12 \\
\hline
\end{tabular}

calculated from the breadth of the diffraction peaks shown in Fig. $2 b$ and the Scherrer formula. This indicated that the particles observed in SEM micrographs were agglomerates of the very small crystals of metal soaps. As seen in Table 2, although magnesium soap was arranged mainly in orthorhombic unit cells, copper and cobalt soaps are mainly in the monoclinic form. The bilayer distance of the alkyl groups also confirms this. Although alkyl groups were perpendicular to metal ion planes in $\mathrm{MgSt}_{2}$ owing to the orthorhombic crystal structure, they were tilted in $\mathrm{CoSt}_{2}$ and $\mathrm{MgSt}_{2}$ owing to the monoclinic structure.

\section{The Mode of Binding of Metal Ions and Carboxylate Groups}

The mode of binding of carboxylate groups to metal ions has been investigated by FTIR spectroscopy.

The mode of binding of the carboxylate groups to metal ions can be elucidated from the FTIR spectra of the soaps (Fig. 3). As reported in Table 3, the asymmetric and symmetric carboxylate vibrations are at 1,580 and $1,429 \mathrm{~cm}^{-1}$ for $\mathrm{MgSt}_{2}$. This indicates that it is in a bridging bidendate form. For $\mathrm{CoSt}_{2}$, there are two asymmetric vibrations at 1,622 and $1,591 \mathrm{~cm}^{-1}$ and the symmetric vibration is at $1,411 \mathrm{~cm}^{-1}$. A shoulder is present at $1,544 \mathrm{~cm}^{-1}$. These vibrations at 1,589 and $1,440 \mathrm{~cm}^{-1}$ have been reported for a bridging complexed structure [20]. The FTIR spectrum of $\mathrm{CoSt}_{2}$ exhibited absorbance at $1,560 \mathrm{~cm}^{-1}$ owing to asymmetric vibration stretching

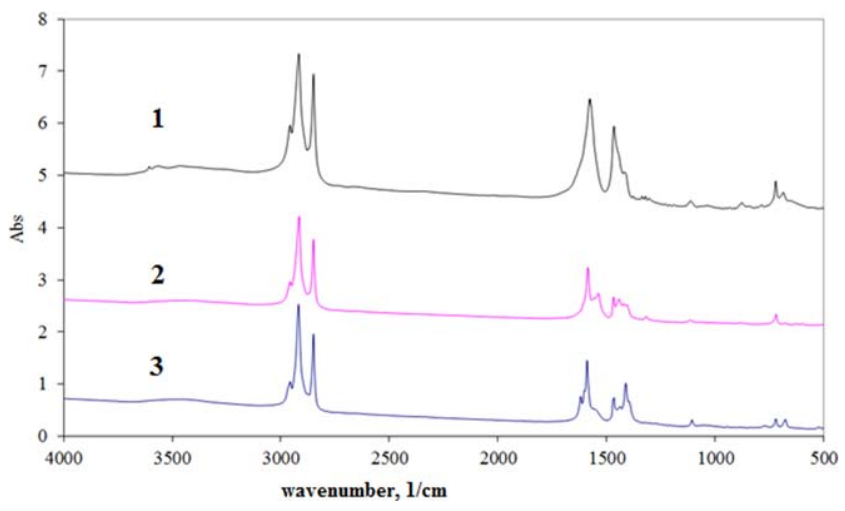

FIG. 3. FTIR spectra of the metal soaps: (1) magnesium soap, (2) copper soap, (3) cobalt soap. [Color figure can be viewed in the online issue, which is available at wileyonlinelibrary.com.]
TABLE 3. Vibrations and their wave numbers for metal soaps.

\begin{tabular}{lccc}
\hline & \multicolumn{3}{c}{ Wave number, $\mathrm{cm}^{-1}$} \\
\cline { 2 - 4 } Vibration & $\mathrm{MgSt}_{2}$ & $\mathrm{CoSt}_{2}$ & $\mathrm{CuSt}_{2}$ \\
\hline \multirow{2}{*}{$\mathrm{CH}_{3}$ stretching } & 2,943 & 2,943 & 2,945 \\
$\mathrm{CH}_{2}$ asymmetric stretching & 2,916 & 2,914 & 2,914 \\
$\mathrm{CH}_{2}$ symmetric stretching & 2,848 & 2,848 & 2,848 \\
$\mathrm{COO}^{-}$asymmetric stretching & 1,580 & $1,622,1,591$, & $1,587-1,535$ \\
& & 1544 & \\
$\mathrm{CH}_{2}$ bending & 1,465 & 1,442 & 1,467 \\
$\mathrm{COO}^{-}$symmetric stretching & 1,429 & 1,411 & 1,419 \\
$\mathrm{C}_{-} \mathrm{O}$ stretching & 1,099 & 1,109 & 1,109 \\
$\mathrm{CH}_{2}$ deformation & 721 & 717 & 719 \\
\hline
\end{tabular}

of the carboxylic group coordinated to the metal ion [5]. $\mathrm{CoSt}_{2}$ has asymmetric and symmetric vibrations of carboxylate groups at 1,589 and $1,440 \mathrm{~cm}^{-1}$, indicating that it exists as a bridging unit in polymeric complex [6]. On the other hand, asymmetric stretching for $\mathrm{CoSt}_{2}$ has been reported at $1,560 \mathrm{~cm}^{-1}$ [5]. The $\mathrm{CoSt}_{2}$ synthesized in the present study by the precipitation method contains stearate mainly in bridging bidendate structure. However, the shoulder at $1,544 \mathrm{~cm}^{-1}$ in the infrared spectrum indicated that monodendate binding also occurred with Co ions. The asymmetric and symmetric vibrations of the carboxylate group are at $1,587 \mathrm{~cm}^{-1}$ and $1,419 \mathrm{~cm}^{-1}$ for $\mathrm{CuSt}_{2}$. The $\mathrm{C}-\mathrm{O}$ antisymmetric stretching vibration of $\mathrm{CuSt}_{2}$ was observed at $1,588 \mathrm{~cm}^{-1}$ [21]. C-O antisymmetric and symmetric vibrations were reported to be at 1,583 and $1,417 \mathrm{~cm}^{-1}$ for a midchain monomethyl branched $\mathrm{C} 17$ copper soap with a distinct hexagonal columnar mesophase [21]. FTIR spectroscopy indicated that all three metal soaps contain stearate mainly in bridging bidendate mode. The soap samples did not contain any water because the spectra contained no peaks assignable to hydrogen bonded $\mathrm{OH}$ groups at $3,400 \mathrm{~cm}^{-1}$ or $\mathrm{H}_{2} \mathrm{O}$ bending vibration at $1,650 \mathrm{~cm}^{-1}$. The spectra do contain peaks related to stretching and bending and deformation of the methylene groups in the metal soaps, as reported in Table 3.

\section{Composition of the Metal Soaps}

The elemental composition of the powders was determined by EDX analysis and reported as hydrogen-free in Table 4. The metal content of the $\mathrm{MgSt}_{2}, \mathrm{CuSt}_{2}$, and $\mathrm{CoSt}_{2}$ was slightly lower than that found from the theoretical formula of the stearates. On the other hand, the carbon contents were slightly higher and oxygen contents were very close to theoretical amounts. Considering the standard deviations of the EDX analysis reported in Table 4, the experimental and theoretical compositions can be accepted as being close to each other. The contribution of the presence of a mixture of palmitates and stearates in the samples was taken into consideration in the theoretical hydrogen-free composition. There were no other impurities such as sodium, chloride, and sulfur in the soaps, indicating there were not any intermediate products such 
TABLE 4. Experimental and theoretical elemental compositions of $\mathrm{Mg} \mathrm{St}_{2}, \mathrm{CoSt}_{2}$, and $\mathrm{CuSt}_{2}$ (mass\%).

\begin{tabular}{|c|c|c|c|c|c|c|}
\hline \multirow[b]{2}{*}{ Element } & \multicolumn{2}{|c|}{ Magnesium soap } & \multicolumn{2}{|c|}{ Cobalt soap } & \multicolumn{2}{|c|}{ Copper soap } \\
\hline & Exp. & Theoretical & Exp. & Theoretical & Exp. & Theoretical \\
\hline $\mathrm{C}$ & $84.10 \pm 0.79$ & 82.26 & $79.93 \pm 0.36$ & 76.85 & $77.92 \pm 0.48$ & 76.19 \\
\hline $\mathrm{O}$ & $11.95 \pm 0.86$ & 12.90 & $10.78 \pm 0.17$ & 12.05 & $11.37 \pm 1.68$ & 11.95 \\
\hline $\mathrm{M}(\mathrm{II})$ & $3.94 \pm 0.30$ & 4.84 & $9.29 \pm 0.35$ & 11.09 & $10.71 \pm 1.39$ & 11.86 \\
\hline
\end{tabular}

as $\mathrm{MgSO}_{4} \mathrm{St}, \mathrm{CoClSt}$, and $\mathrm{CuSO}_{4} \mathrm{St}$ in the soaps prepared by the precipitation method in the present study. Also, no crystal water was present in the samples; they were anhydrous. Otherwise, higher oxygen contents would be observed for the samples.

\section{Color of the Soaps}

The color of the metal soaps was quantitatively measured, and their $L, a$, and $b$ values are reported in Table 5, where $L$ represents the lightness of the color; positive values of " $a$ " represent the redness; negative values of " $a$ " represent greenness; positive values of " $b$ " represent yellowness, and negative values of " $b$ " represent blueness of the color. The magnesium soap was white; the cobalt soap was light purple, and copper stearate was turquoise (Fig. 4). Purple $\mathrm{CoSt}_{2}$ was also reported previously [22]. The colors of the cobalt and copper soaps are due to light absorption to promote the electrons from $e_{\mathrm{g}}$ to $t_{2 \mathrm{~g}}$ levels.

\section{The Thermal Behavior of the Metal Soaps}

The solid-liquid phase transitions in metal soaps were investigated by using optical microscopy. The optical micrographs of the soaps were recorded at different time periods during heating at a rate of $2^{\circ} \mathrm{C} / \mathrm{min}$. The soaps did not transmit light when in the solid state and they appear as dark regions in the micrographs. When they were liquefied, the edges of the particles were rounded and the particles became transparent. The complete liquefaction of $\mathrm{MgSt}_{2}, \mathrm{CoSt}_{2}$, and $\mathrm{CuSt}_{2}$ was completed at $160^{\circ} \mathrm{C}, 159^{\circ} \mathrm{C}$, and $117^{\circ} \mathrm{C}$, respectively. The micrographs are seen in Fig. 5.

The thermal transitions of metal soaps during programmed heating can be determined by analysis by differential scanning calorimetry (DSC) [18, 23].

The DSC analyses provide information about energy changes during heating of the substances. The DSC curves for the metal soaps are shown in Fig. 6. Water of

TABLE 5. $L, a, b$ values, and colors of metal soaps.

\begin{tabular}{lcccl}
\hline Soap & $L$ & $a$ & $B$ & \multicolumn{1}{c}{ Color } \\
\hline $\mathrm{MgSt}_{2}$ & 117.13 & -1.2 & -4.90 & White \\
$\mathrm{CoSt}_{2}$ & 90.22 & 15.37 & -22.97 & Purple \\
$\mathrm{CuSt}_{2}$ & 109.4 & -24.09 & -10.36 & Light blue \\
\hline
\end{tabular}

hydration was lost at $100^{\circ} \mathrm{C}$ and melting peaks at $120^{\circ} \mathrm{C}$ and $130^{\circ} \mathrm{C}$ were observed for magnesium stearate mononohydrate and dihydrate, respectively, in previous studies. For the trihydrate, a two-stage melting endotherm starting at $115^{\circ} \mathrm{C}$ was observed [23]. There is a solid phase transition at $57^{\circ} \mathrm{C}$ in the DSC curve for $\mathrm{MgSt}_{2}$. The melting endotherm of $\mathrm{MgSt}_{2}$ was observed at $115^{\circ} \mathrm{C}$ by $\mathrm{DSC}$ analysis. However, the liquefaction of $\mathrm{MgSt}_{2}$ was completed at $160^{\circ} \mathrm{C}$ as indicated by the micrographs shown in Fig. 5. The thermal transition from the solid phase to liquid phase occurs at $115^{\circ} \mathrm{C}$, but to obtain an easily flowing liquid a higher temperature, $160^{\circ} \mathrm{C}$ is required. The presence of an ordered hexagonal phase with molten alkyl tails that exists in liquid phase up to $190^{\circ} \mathrm{C}$ has previously been reported [18]. The broad and small endotherm observed in the range of $160-190^{\circ} \mathrm{C}$ for $\mathrm{MgSt}_{2}$ could be due to disordering of the hexagonal phase. The DSC curve of $\mathrm{CoSt}_{2}$ contains a small endothermic peak at $140^{\circ} \mathrm{C}$ and a large endotherm at $159^{\circ} \mathrm{C}$. $\mathrm{CoSt}_{2}$ exists in three different crystalline phases $(\mathrm{Cr} 1, \mathrm{Cr} 2$, and $\mathrm{Cr} 3)$, one mesophase (M), and an isotropic liquid phase (I). The transition temperatures for the phase changes are 308.1, 380.9, and $404.4 \mathrm{~K}$ for $\mathrm{Cr} 2$ to $\mathrm{Cr} 1, \mathrm{Cr} 1$ to $\mathrm{M}$, and $\mathrm{M}$ to $\mathrm{I}$ phases, respectively [22]. The endotherm at $140^{\circ} \mathrm{C}$ is close to the transition temperature of $131^{\circ} \mathrm{C}$ from mesophase to liquid crystal phase reported earlier [22]. A complete liquefaction of liquid crystal phase of $\mathrm{CoSt}_{2}$ at $159^{\circ} \mathrm{C}$ was also seen in the optical micrographs (Fig. 5d, $\mathrm{e}$, and f). For copper stearate, only one endotherm is present at $111^{\circ} \mathrm{C}$ in the DSC curve. It is the transition temperature from the solid to liquid phase, as confirmed by optical micrographs shown in Fig. 5g, h, and i.

Metal soaps decompose on heating to high temperatures. The thermal gravimetry (TG) analysis curves of the soaps are shown in Fig. 7. The onset of thermal

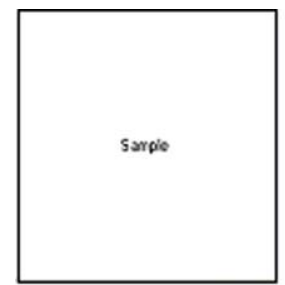

(a)

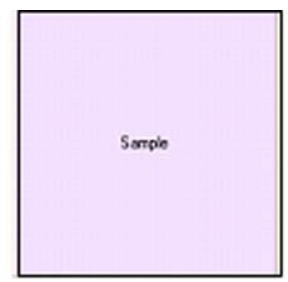

(b)

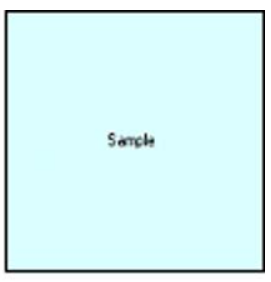

(c)
FIG. 4. The colors of the metal soaps: (a) magnesium soap, (b) cobalt salt, (c) copper soap. [Color figure can be viewed in the online issue, which is available at wileyonlinelibrary.com.] 

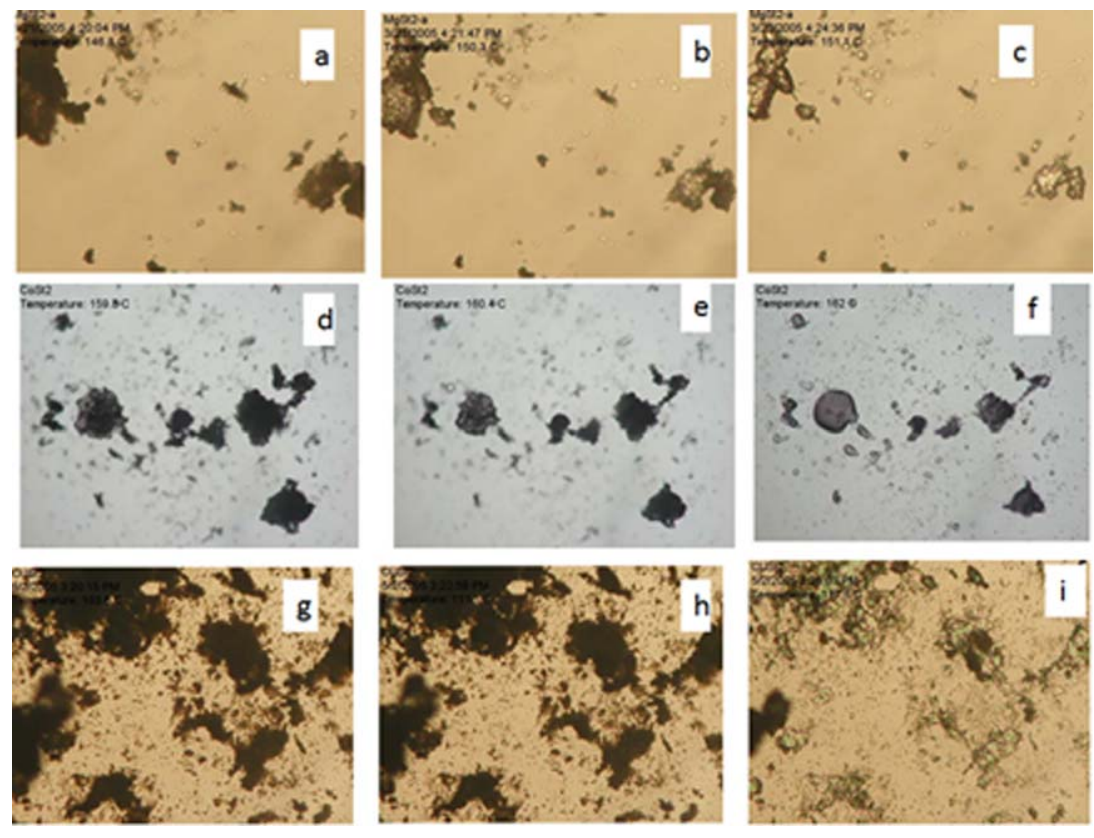

FIG. 5. Optical micrographs of $\mathrm{MgSt}_{2}$ at (a) $146.8^{\circ} \mathrm{C}$, (b) $150.2^{\circ} \mathrm{C}$, (c) $151.1^{\circ} \mathrm{C} ; \mathrm{CoSt}_{2}$ at (d) $150.8^{\circ} \mathrm{C}$, (e) $160.4^{\circ} \mathrm{C}$, (f) $162^{\circ} \mathrm{C}$; $\mathrm{CuSt}_{2}$ at (g) $103^{\circ} \mathrm{C},(\mathrm{h})$ $111^{\circ} \mathrm{C}$, (i) $117.5^{\circ} \mathrm{C}$ at $\times 400$ magnification. [Color figure can be viewed in the online issue, which is available at wileyonlinelibrary.com.]

degradation was $322^{\circ} \mathrm{C}, 342^{\circ} \mathrm{C}$, and $255^{\circ} \mathrm{C}$ for $\mathrm{MgSt}_{2}$, $\mathrm{CoSt}_{2}$, and $\mathrm{CuSt}_{2}$, respectively (Table 6). The $342^{\circ} \mathrm{C} \mathrm{deg-}$ radation onset temperature of $\mathrm{CoSt}_{2}$ is higher than the $291.3^{\circ} \mathrm{C}$ reported for $\mathrm{Co}\left(\mathrm{OOCC}_{17} \mathrm{H}_{35}\right)_{3} \cdot 2 \mathrm{H}_{2} \mathrm{O}$ [5]. This also confirms that the $\mathrm{CoSt}_{2}$ in the present study was in the anhydrous state.

Metal oxides and stearic acid are formed on heating metal soaps at high temperatures [24, 25]. However, for the metal soaps under study, the following reactions shown by Eqs. 2-4 were expected to occur during their heating at high temperatures:

$$
\begin{gathered}
\mathrm{Mg}\left(\mathrm{C}_{17} \mathrm{H}_{35} \mathrm{COO}\right)_{2} \rightarrow \mathrm{MgO}+\mathrm{C}_{17} \mathrm{H}_{35} \mathrm{COC}_{17} \mathrm{H}_{35}+\mathrm{CO}_{2} \\
\mathrm{Co}\left(\mathrm{C}_{17} \mathrm{H}_{35} \mathrm{COO}\right)_{2} \rightarrow \mathrm{CoO}+\mathrm{C}_{17} \mathrm{H}_{35} \mathrm{COC}_{17} \mathrm{H}_{35}+\mathrm{CO}_{2}
\end{gathered}
$$

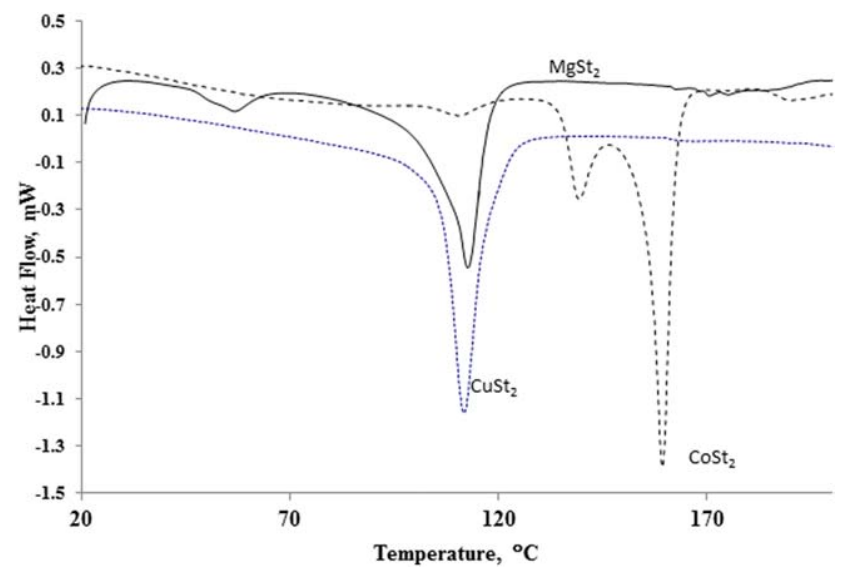

FIG. 6. DSC curves of $\mathrm{MgSt}_{2}, \mathrm{CoSt}_{2}, \mathrm{CuSt}_{2}$. [Color figure can be viewed in the online issue, which is available at wileyonlinelibrary. com.]

$$
\mathrm{Cu}\left(\mathrm{C}_{17} \mathrm{H}_{35} \mathrm{COO}\right)_{2} \rightarrow \mathrm{CuO}+\mathrm{C}_{17} \mathrm{H}_{35} \mathrm{COC}_{17} \mathrm{H}_{35}+\mathrm{CO}_{2}
$$

Metal oxides, distearyl ketone, and carbon dioxide are possible reaction products. Distearyl ketone will be further pyrolyzed to volatile compounds and carbon-rich nonvolatile compounds. The percentages of mass remaining at $600^{\circ} \mathrm{C}$ are $22.0 \%, 31.8 \%$, and $39.2 \%$ for $\mathrm{MgSt}_{2}$, $\mathrm{CoSt}_{2}$, and $\mathrm{CuSt}_{2}$, respectively. They were higher than the oxide mass percentage of the soaps (i.e., 6\%, 11.2\%, and $13.6 \%$ for $\mathrm{MgSt}_{2}, \mathrm{CoSt}_{2}$, and $\mathrm{CuSt}_{2}$, respectively), confirming the carbonization of the distearyl ketone.

The TG curves were analyzed by using Broido's method [26]. For a first-order decomposition reaction:

$$
\ln [\ln (1 / \alpha)]=-E /(R T)+C
$$

where $\alpha$ is the extent of reaction, $E$ is the activation energy of the decomposition, $T$ is the absolute temperature, $R$ is the gas constant, and $C$ is a constant. The plot of $\ln [\ln (1 / \alpha)]$ vs. $1 / T$ is linear and its slope is equal to $-E / R$.

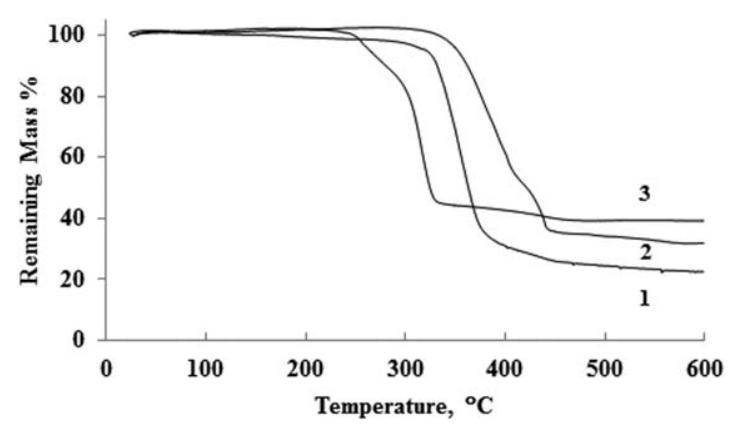

FIG. 7. TG curves of metal soaps: (1) $\mathrm{MgSt}_{2}$, (2) $\mathrm{CoSt}_{2}$, (3) $\mathrm{CuSt}_{2}$. 
TABLE 6. Onset temperature, remaining mass at $600^{\circ} \mathrm{C}$, and activation energy values from Broido's method for thermal degradation of metal soaps.

\begin{tabular}{lccc}
\hline & $\begin{array}{c}\text { Onset temperature } \\
\text { of degradation, }{ }^{\circ} \mathrm{C}\end{array}$ & $\begin{array}{c}\text { Remaining } \\
\text { mass at } \\
600^{\circ} \mathrm{C}, \%\end{array}$ & $\begin{array}{c}\text { Activation energy } \\
\text { of decomposition, } \\
\mathrm{kJ} / \mathrm{mol}\end{array}$ \\
\hline $\mathrm{MgSt}_{2}$ & 322 & 22.0 & 121 \\
$\mathrm{CoSt}_{2}$ & 342 & 31.8 & 72 \\
$\mathrm{CuSt}_{2}$ & 255 & 39.2 & 18 \\
\hline
\end{tabular}

The TG data for metal soaps are plotted as $\ln [\ln (1 / \alpha)]$ vs. $1 /$ $T$, and straight lines with 0.99 regression coefficients were obtained as seen in Fig. 8. The activation energies for thermal decomposition of metal stearates were determined as $121 \mathrm{~kJ} / \mathrm{mol}, 72 \mathrm{~kJ} / \mathrm{mol}$, and $18 \mathrm{~kJ} / \mathrm{mol}$ for $\mathrm{MgSt}_{2}, \mathrm{CoSt}_{2}$, and $\mathrm{CuSt}_{2}$, respectively (Table 6). The activation energy of decomposition of metal soaps of rubber seed oil were previously determined to be in the range of 52-96 kJ/mol [27]. The activation energy for the decomposition of $\mathrm{CuSt}_{2}, 18 \mathrm{~kJ} /$ mol, is lower than that of $\mathrm{MgSt}_{2}$ and $\mathrm{CoSt}_{2}$. The rate of thermal degradationof $\mathrm{CuSt}_{2}$ increased faster with increasing temperature compared with that of $\mathrm{MgSt}_{2}$ and $\mathrm{CuSt}_{2}$. The onset of thermal degradation was taken as the temperature at which the remaining mass was $98 \%$. These were $322^{\circ} \mathrm{C}$, $342^{\circ} \mathrm{C}, 255^{\circ} \mathrm{C}$ for $\mathrm{MgSt}_{2}, \mathrm{CoSt}_{2}$, and $\mathrm{CuSt}_{2}$, respectively. $\mathrm{CuSt}_{2}$ started to degrade at a lower temperature, and the increase in rate with increasing temperature is higher than that of $\mathrm{CoSt}_{2}$ and $\mathrm{MgSt}_{2}$. On the other hand, the onset of degradation is $342^{\circ} \mathrm{C}$ for $\mathrm{CoSt}_{2}$, and the increase in decomposition rate is faster than $\mathrm{MgSt}_{2}$ and slower than $\mathrm{CuSt}_{2}$. In other words, copper ions acted as a catalyst to lower the activation energy of decomposition of the carboxylate.

\section{Effect of Metal Soaps on Dehydrochlorination of PVC}

The dehydrochlorination of PVC is initiated at labile chlorine atoms next to tertiary, carbonyl, or allylic groups.Conjugated polyenes are formed by a radical chain process:

$$
\operatorname{PVC}(\mathrm{s}) \rightarrow \operatorname{dePVC}(\mathrm{s})+\mathrm{HCl}(\mathrm{g})
$$

where dePVC represents the PVC having conjugated polyenes. Formed $\mathrm{HCl}$ acts as a catalyst for dehydrochlorination and accelerates the dehydrochlorination reaction. Metal soaps prevent dehydrochlorination of PVC by replacement of labile chlorine atoms of PVC with the carboxylate group [28]:

$$
\mathrm{MSt}_{2}+-\mathrm{CH}_{2} \mathrm{CHCl}-\rightarrow \mathrm{MCl}_{2}+2-\mathrm{CH}_{2} \mathrm{CHSt}-
$$

The bond between the carbon and carboxylate group is more stable compared with labile carbon chlorine bond. The metal ion of the soap has an important effect on the formation of carbon and carboxylate bond. $\mathrm{MCl}_{2}$ formed as a consequence of the substitution reaction may have an accelerating effect on dehydrochlorination if it is a Lewis acid [29].
However, there are reports about effectiveness of metal decanoates in promoting dehydrochlorination of chlorinated polymers [30]. Metal formates were also investigated for this purpose. Metal formates with low cation acidity were ineffective as stabilizers for vinylidene chloride copolymers. At the other extreme, metal formates that contain cations sufficiently acidic to actively strip chlorine from the polymer backbone enhanced the degradation process. An effective carboxylate stabilizer must contain a metal cation sufficiently acidic to interact with allylic chlorine and to facilitate its displacement by the carboxylate anion. Copper(II) formate had the balance of cation acidity and carboxylate activity to function as an effective stabilizer for vinylidene chloride copolymers [31].

Thus, the effects of soaps containing magnesium, cobalt, and copper ions on PVC dehydrochlorination were investigated in the present study. First, homogeneous mixtures of the metal soap and PVC powders were prepared as described in Experimental section for this purpose. This was possible because the particle size of the PVC powder used in the study was $300 \mathrm{~nm}$ [17] and the lamellar thickness of the metal soaps was also around $50 \mathrm{~nm}$, as seen in Fig. 1. During thermal stability tests at $140^{\circ} \mathrm{C}$ and $160^{\circ} \mathrm{C}$, the $\mathrm{MgSt}_{2}$ and $\mathrm{CuSt}_{2}$ were in the liquid state and PVC particles were in the solid state. However, $\mathrm{CoSt}_{2}$ was in the solid state at $140^{\circ} \mathrm{C}$ and in the liquid state at $160^{\circ} \mathrm{C}$. The metal soaps were thermally stable at these temperatures. A heterogeneous reaction took place between metal soaps and PVC particles, because they were not in the same phase. The reaction of the metal soaps with PVC particles occurred at the surface. However, the interior of the PVC particles cannot interact with the soaps and presumably this is where the dehydrochlorination started. The $\mathrm{HCl}$ gas formed by PVC dehydrochlorination could react with metal soaps to give stearic acid and metal chlorides.

$$
\begin{aligned}
& \mathrm{MgSt}_{2}+2 \mathrm{HCl} \rightarrow 2 \mathrm{HSt}+\mathrm{MgCl}_{2} \\
& \mathrm{CoCl}_{2}+2 \mathrm{HCl} \rightarrow 2 \mathrm{HSt}+\mathrm{CoCl}_{2} \\
& \mathrm{CuCl}_{2}+2 \mathrm{HCl} \rightarrow 2 \mathrm{HSt}+\mathrm{CuCl}_{2}
\end{aligned}
$$

Thus, $\mathrm{HCl}$ is scavenged by the metal soaps. The metal chlorides are Lewis acids and they accelerate the dehydrochlorination reaction after their concentration reaches a certain level [29]. The onset and stability times for the samples with different metal soaps are

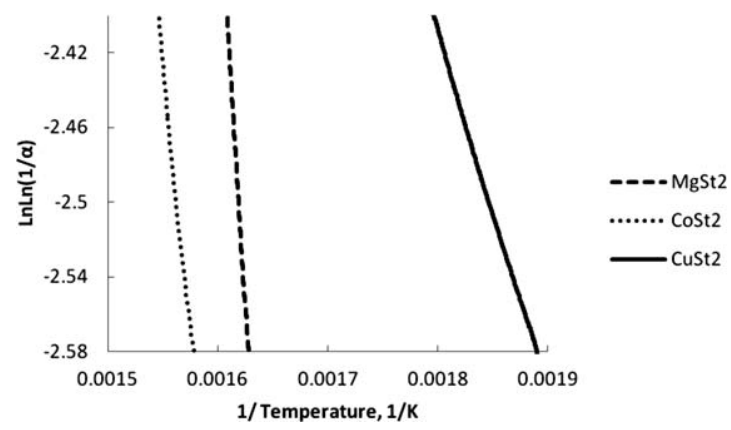

FIG. 8. Broido's plot for (1) cobalt soap, (2) magnesium soap, (3) copper soap. 
TABLE 7. Induction and stability times, the activation energies, and the preexponential factors for PVC dehydrochlorination.

\begin{tabular}{|c|c|c|c|c|c|c|c|c|}
\hline \multirow[b]{2}{*}{ Sample } & \multicolumn{2}{|c|}{ Induction time, $\mathrm{h}$} & \multicolumn{2}{|c|}{ Stability time, h } & \multicolumn{2}{|c|}{ Rate constant, $\mathrm{s}^{-1}$} & \multirow[b]{2}{*}{$E_{\mathrm{a}}, \mathrm{kJ} / \mathrm{mol}$} & \multirow[b]{2}{*}{$A, \mathrm{~s}^{-1}$} \\
\hline & $140^{\circ} \mathrm{C}$ & $160^{\circ} \mathrm{C}$ & $140^{\circ} \mathrm{C}$ & $160^{\circ} \mathrm{C}$ & $140^{\circ} \mathrm{C}$ & $160^{\circ} \mathrm{C}$ & & \\
\hline PVC & 5.98 & 0.69 & 14.83 & 1.40 & $2.61 \times 10^{-7}$ & $3.48 \times 10^{-6}$ & 192 & $5.9 \times 10^{17}$ \\
\hline $\mathrm{PVC}+\mathrm{MgSt}_{2}$ & 3.65 & 0.88 & 7.52 & 1.62 & $5.92 \times 10^{-7}$ & $3.18 \times 10^{-6}$ & 125 & $3.9 \times 10^{9}$ \\
\hline $\mathrm{PVC}+\mathrm{CoSt}_{2}$ & 9.70 & 2.04 & 10.57 & 2.55 & $1.04 \times 10^{-6}$ & $3.58 \times 10^{-6}$ & 92 & $4.1 \times 10^{5}$ \\
\hline $\mathrm{PVC}+\mathrm{CuSt}_{2}$ & 2.16 & 0.53 & 4.43 & 1.05 & $9.40 \times 10^{-7}$ & $5.69 \times 10^{-6}$ & 133 & $8.6 \times 10^{10}$ \\
\hline
\end{tabular}

reported in Table 7. Figures 9 and 10 show the change of conductivity of the test solution with respect to time for the PVC samples heated at $140^{\circ} \mathrm{C}$ and $160^{\circ} \mathrm{C}$, respectively. Induction time corresponds to the time for the start of $\mathrm{HCl}$ evolution to gas phase. Stability time corresponds to a fixed extent of dehydrochlorination that will increase the conductivity of the test solution to $50 \mathrm{mS}$.

For the first-order dehydrochlorination reaction,

$$
-\ln c=k t+\ln c_{\mathrm{o}}
$$

where $k$ is the rate constant, $t$ is the time, and $c$ and $c_{\mathrm{o}}$ are the concentrations of $\mathrm{HCl}$ in PVC available for dehydrochlorination reaction at any time and at initial time, respectively. The reaction rate constants after the start of the dehydrochlorination reaction were determined from the slopes of the conductivity vs. time curves by using the method reported [29]. The preexponential factor, A, and the activation energy, $E$, were found from the rate constants at 140 and $160^{\circ} \mathrm{C}$ by using the Arrhenius equation

$$
k=A e^{-E / R T}
$$

The induction time, stability time, the activation energy, and preexponential factors for the dehydrochlorination reaction are as reported in Table 7 .

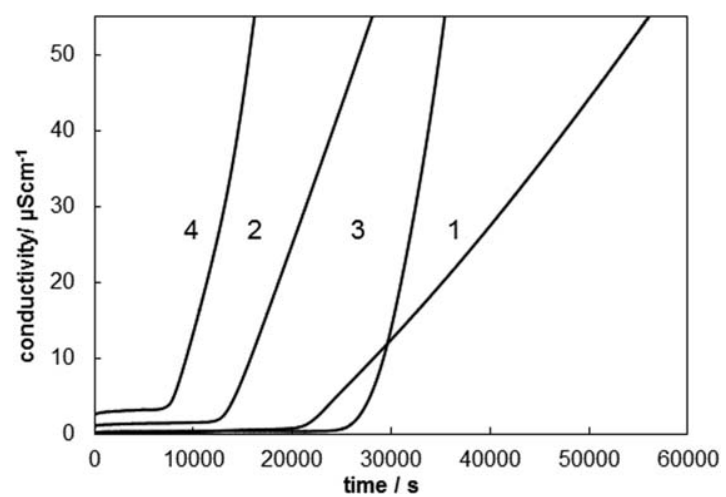

FIG. 9. PVC dehydrochlorination kinetic curves obtained with $\mathrm{PVC}$ Thermomat 763 at $140^{\circ} \mathrm{C}$ : (1) $\mathrm{PVC}$, (2) $\mathrm{PVC}+\mathrm{MgSt}_{2}$, (3) $\mathrm{PVC}+\mathrm{CoSt}_{2}$, (4) $\mathrm{PVC}+\mathrm{CuSt}_{2}$.
Although $\mathrm{CoSt}_{2}$ retarded the onset of the evolution of $\mathrm{HCl}$ from PVC at $140^{\circ} \mathrm{C}, \mathrm{MgSt}_{2}$, and $\mathrm{CuSt}_{2}$ accelerated this process. At $160^{\circ} \mathrm{C}$, the induction times for degradation of PVC containing $\mathrm{MgSt}_{2}(0.88 \mathrm{~h})$ and $\mathrm{CoSt}_{2}(2.02 \mathrm{~h})$ were higher than that for pure PVC $(0.69 \mathrm{~h})$. For the $\mathrm{CuSt}_{2}$ containing polymer, this period is shorter, $0.53 \mathrm{~h}$.

The stability times for PVC with metal soaps are shorter than that of $\mathrm{PVC}$ at $140^{\circ} \mathrm{C}$. However, at $160^{\circ} \mathrm{C}$ $\mathrm{MgSt}_{2}$ and $\mathrm{CoSt}_{2}$ containing PVC samples have longer stability times (1.62 $\mathrm{h}$ and $2.55 \mathrm{~h}$, respectively) than that of pure PVC (1.4 h). $\mathrm{CuSt}_{2}$ containing PVC had a shorter stability time, $1.05 \mathrm{~h}$.

$\mathrm{CoSt}_{2}$ retarded both dehydrochlorination onset and stability time at $140^{\circ} \mathrm{C}$ and $160^{\circ} \mathrm{C}$. Different modes of binding of the carboxylate groups to cobalt ions (both as monodendate and bidendate) may allow the easier substitution of labile chlorine atoms by the carboylate group.

When the activation energies of dehydrochlorination reported in Table 6 were compared, it is very clear that the dehydrochlorination reaction in the presence of metal soaps is more facile than in their absence. The activation energy of dehydrochlorination of PVC decreased from $192 \mathrm{~kJ} / \mathrm{mol}$ for PVC to 125,92 , and 133 $\mathrm{kJ} / \mathrm{mol}$ for $\mathrm{MgSt}_{2}, \mathrm{CoSt}_{2}$, and $\mathrm{CuSt}_{2}$ containing PVC samples, respectively. Thus, the three metal soaps investigated in this study accelerated the rate of dehydrochlorination of PVC, because their chlorides acted as strong Lewis acids [29].

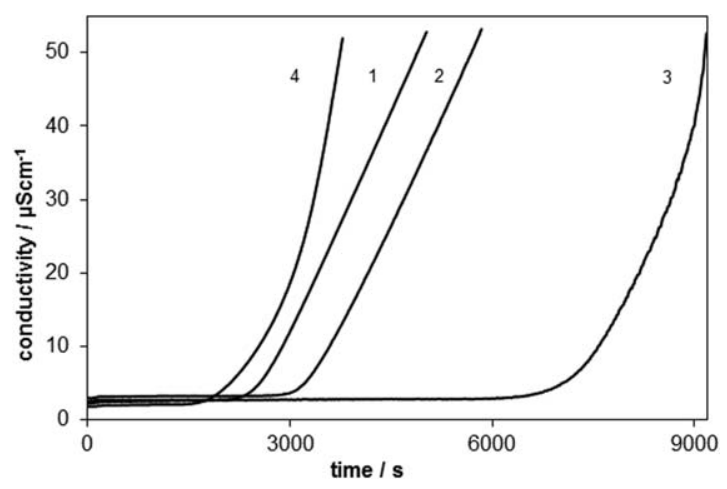

FIG. 10. PVC dehydrochlorination kinetic curves obtained with $\mathrm{PVC}$ Thermomat 763 at $160^{\circ} \mathrm{C}$ : (1) $\mathrm{PVC}$, (2) $\mathrm{PVC}+\mathrm{MgSt}_{2}$, (3) $\mathrm{PVC}+\mathrm{CoSt}_{2}$, (4) $\mathrm{PVC}+\mathrm{CuSt}_{2}$. 
TABLE 8. $L, a, b$ values of PVC powder after thermal stability test by PVC Thermomat.

\begin{tabular}{|c|c|c|c|c|c|c|}
\hline \multirow[b]{2}{*}{ Sample } & \multicolumn{3}{|c|}{$140^{\circ} \mathrm{C}$} & \multicolumn{3}{|c|}{$160^{\circ} \mathrm{C}$} \\
\hline & $L$ & $a$ & $b$ & $L$ & $a$ & $b$ \\
\hline PVC & 44.55 & 14.16 & 9.67 & 47.36 & 15.32 & 13.58 \\
\hline $\mathrm{PVC}+\mathrm{MgSt}_{2}$ & 45.49 & 13.58 & 6.04 & 42.63 & 16.64 & 15.24 \\
\hline $\mathrm{PVC}+\mathrm{CoSt}_{2}$ & 45.32 & 18.01 & 20.27 & 48.05 & 17.93 & 27.33 \\
\hline $\mathrm{PVC}+\mathrm{CuSt}_{2}$ & 46.87 & 8.97 & 22.46 & 50.79 & 7.66 & 23.68 \\
\hline
\end{tabular}

\section{Color of PVC After Thermal Stability Tests}

There are reports about the prevention of discoloration of PVC by metal soaps. For example, $\mathrm{CdSt}_{2}$ added to PVC having allylic chlorines did not prevent elimination of $\mathrm{HCl}$ from PVC, but it prevented the discoloration of PVC. This was based on the ability of the metals to form complexes with the chlorine atoms of the polymeric chain; thus, the formation of long polyene sequences that caused discoloration was prevented [32]. The $L, a$, and $b$ values of the thermally degraded samples after the PVC Thermomat tests are reported in Table 8 and their colors are seen in Fig. 11. All the samples had evolved the same amount of $\mathrm{HCl}$ since the test was stopped when the conductivity of the test solution was $50 \mathrm{mS}$. The color of the samples had a purple tint (Fig. 11). All samples were discolered nearly to the same extent at $140^{\circ} \mathrm{C}$; however, PVC mixed with metal soaps had slightly higher $L$ values (45.32-46.87) than pure PVC (44.55). On the other hand, $160^{\circ} \mathrm{C}$ PVC containing $\mathrm{CuSt}_{2}$ has the highest $L$ value (50.79) and $\mathrm{MgSt}_{2}$ had the lowest $L$ value (42.63) among all the samples. As the length of the polyene sequences in PVC increased, the color changed in the order of yellow (6-enes), red (11-enes), violet (15-enes) [33], brown, and black. Dehydrochlorinated PVC with copper soap had the smallest redness (a value) at both $140^{\circ} \mathrm{C}$ and $160^{\circ} \mathrm{C}$. Thus, the concentration of

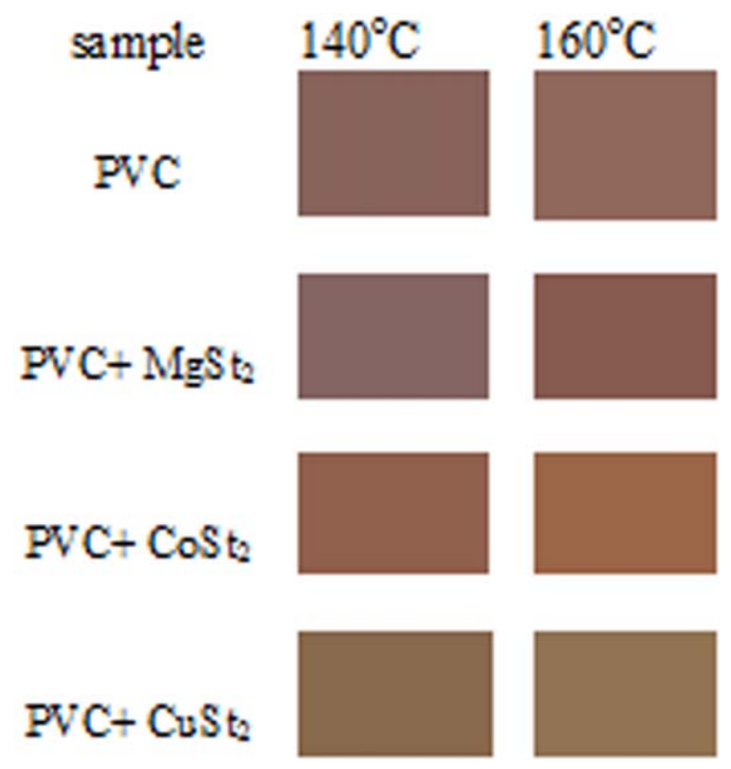

FIG. 11. Color of PVC samples after thermal stability tests. [Color figure can be viewed in the online issue, which is available at wileyonlinelibrary.com.] short polyene sequences is lowest for $\mathrm{PVC}$ having $\mathrm{CuSt}_{2}$. PVC with $\mathrm{CoSt}_{2}$ and $\mathrm{CuSt}_{2}$ had higher $b$ values, indicating they have a high concentration of shorter polyene sequences confirming previous studies with $\mathrm{CdSt}_{2}$ [32]. The smallest $b$ value was obseved for $\mathrm{PVC}$ with $\mathrm{MgSt}_{2}$ at $140^{\circ} \mathrm{C}$ and for control $\mathrm{PVC}$ at $160^{\circ} \mathrm{C}$, indicating that they had smallest concentration of long polyene sequences.

\section{CONCLUSION}

Anhydrous $\mathrm{MgSt}_{2}, \mathrm{CoSt}_{2}$, and $\mathrm{CuSt}_{2}$ were obtained from a precipitation reaction of $\mathrm{NaSt}$ and metal salts in aqueous solutions and drying at reduced pressure at $105^{\circ} \mathrm{C} . \mathrm{MgSt}_{2}$, $\mathrm{CoSt}_{2}$, and $\mathrm{CuSt}_{2}$ were white, purple, and light blue, respectively. The bilayer distances of the crystals were $5.0 \mathrm{~nm}$, $4.7 \mathrm{~nm}$, and $4.5 \mathrm{~nm}$ for $\mathrm{MgSt}_{2}, \mathrm{CoSt}_{2}$, and $\mathrm{CuSt}_{2}$, respectively. Although $\mathrm{MgSt}_{2}$ had orthorhombic crystals, $\mathrm{CoSt}_{2}$ and $\mathrm{CuSt}_{2}$ crystallized in monoclinic form. Their solidliquid phase transition temperatures were observed by optical microscopy at $160^{\circ} \mathrm{C}, 159^{\circ} \mathrm{C}$, and $117^{\circ} \mathrm{C}$ for $\mathrm{MgSt}_{2}$, $\mathrm{CoSt}_{2}$, and $\mathrm{CuSt}_{2}$, respectively. However, the melting points of $\mathrm{MgSt}_{2}, \mathrm{CoSt}_{2}$, and $\mathrm{CuSt}_{2}$ were determined as $115^{\circ} \mathrm{C}$, $159^{\circ} \mathrm{C}$, and $111^{\circ} \mathrm{C}$, respectively, by DSC analysis. The onset temperature of the mass loss was the lowest, $255^{\circ} \mathrm{C}$, for $\mathrm{CuSt}_{2}$ and the lowest activation energy for thermal decomposition was also observed for $\mathrm{CuSt}_{2}$ as $18 \mathrm{~kJ} / \mathrm{mol}$.

$\mathrm{CoSt}_{2}$ was effective in increasing the induction and stability times of PVC dehydrochlorination at both $140^{\circ} \mathrm{C}$ and $160^{\circ} \mathrm{C}$. However, the activation energy of PVC dehydrochlorination $(92 \mathrm{~kJ} / \mathrm{mol})$ was lowest for the $\mathrm{CoSt}_{2}$-containing sample. All three metal soaps accelerated dehydrochlorination of PVC by providing an alternative pathway at a lower activation energy. They could be recommended as dehydrochlorination catalysts for the recovery of $\mathrm{HCl}$ in PVC waste-processing plants. However, further studies should be made by mixing metal soaps and PVC at the molecular level by using an extruder, to better explain the effect of metal soaps in PVC dehydrochlorination.

\section{ACKNOWLEDGMENTS}

The authors thank the TUBITAK for the financial support (MISAG 185).

\section{REFERENCES}

1. M.S. Akanni, E.K. Okoh, H.D. Burrows, and H.A. Ellis, Thermochim. Acta, 208, 1 (1992). 
2. M. Gonen, D. Balkose, F. Inal, and S. Ulku, Ind. Eng. Chem. Res., 44, 1627 (2005).

3. M. Gonen, S. Ozturk, D. Balkose, and S. Ulku, Ind. Eng. Chem. Res., 49,1732 (2010).

4. P.K. Roy, P. Surekha, C. Rajagopal, and V. Choudhary, Polym. Lett., 1, 208 (2007).

5. P.K. Roy, P. Surekha, C. Rajagopal, and V. Choudhary, Polym. Degrad. Stab., 91, 1980 (2006).

6. Y. Huang, D.K. Sarkar, and X.G.A. Chen, Mater. Lett., 64, 2722 (2010).

7. P. Bracconi, C. Andres, and A. Ndiaye, Int. J. Pharm., 262, 109 (2005).

8. S. Patel, A.M. Kaushal, and A.K. Bansal, AAPS Pharm. Sci. Technol., 8, E1 (2007).

9. Q.T. Zhou, L. Qu, I. Larson, P.J. Stewart, and D.A.V. Morton, Int. J. Pharm., 394, 50 (2010).

10. K.A. Sheikh, Y.B. Kang, J.J. Rouse, and G.M. Eccleston, Int. J. Pharm., 411, 121 (2011).

11. Q.Y. Liu, X.H. Guo, Y. Li, and W. Shen, Langmuir, 25, 6425 (2009).

12. S. Grosshans-Vieles, F. Tihay-Schweyer, P. Rabu, J.L. Paillaud, P. Braunstein, B. Lebeau, C. Estournes, J.L. Guille, and J.M. Rueff, Microporous Mesoporous Mater., 106, 17 (2007).

13. A.P. Filippov, P.E. Strizhak, and V.G. Il'in, Sens. Actuators B., 126, 375 (2007).

14. P. Simon, P. Oremusava, L. Valko, and P. Kovarik, Chem. Pap., 45, 127 (1991).

15. H. Zhu, W. Wang, and T. LiU, J. Appl. Polym. Sci., 122, 273 (2011).

16. Y.-B. Liu, W.-Q. Liu, and M.-H. Hou, Polym. Degrad. Stab., 97, 1565 (2007).

17. S.A. Savrik, D. Balkose, S. Ulutan, and S. Ulku, J. Therm. Anal. Calorim., 101, 801 (2010).
18. K. Wakabayashi and R.A. Register, Ind. Eng. Chem. Res., 49, 11906 (2010).

19. J.L. White and D. Cho, Polyolefines: Processing, Structure Developments and Properties, Hanser Verlag, Munich (2001).

20. E. Jona, D. Ondrusova, M. Pajtasova, P. Simon, and J. Michaler, J. Appl. Polym. Sci., 81, 2936 (2001).

21. I. Satake and R. Mature, Kolloid-Zeitschrift, 176, 31 (1960).

22. G.R. Van Hecke, T. Nakamoto, T.G. Clements, and M. Sora, Liq. Cryst., 30, 831 (2003).

23. M. Koivista, H. Jalonen, and V.P. Lehto, Powder Technol., 147, 79 (2004).

24. L.M. Bronstein, J.E. Atkinson, A.G. Malyutin, F. Kidwai, B.D. Stein, D.G. Morgan, J.M. Perry, and J.A. Karty, Langmuir, 7, 3044 (2011).

25. C. Chen, H. Lai, C. Lin, J. Wang, and R. Chiang, Nanoscale Res. Lett., 4, 1343 (2009).

26. A. Broido, J. Polym. Sci., Part B: Polym. Phys., 7, 1761 (1969).

27. D. Balkose, T.O. Egbuchunam, and F.O. Okeimen, J. Therm. Anal. Calorim., 101, 795 (2010).

28. A.H. Frye and R.W. Horst, J. Polym. Sci., 4, 51 (1960).

29. S. Atakul, D. Balkose, and S. Ulku, J. Vinyl Addit. Technol., 11, 47 (2005).

30. B.A. Howell and A.Q. Campbell, Thermochim. Acta, 340, 231 (1999).

31. B.A. Howell and W.J. Rajaram, J. Vinyl Technol., 15, 202 (1993).

32. Z. Vymazal, L. Mastny, and Z. Vymazalová, Eur. Polym. J., 25, 1069 (1989).

33. E.A. Braude and F.C. Nachod, Determination of Organic Structures by Physical Methods, Academic Press, New York (1955). 